\title{
Diet as a system: an observational study investigating a multi-choice system of moderately restricted low-protein diets
}

Giorgina Barbara Piccoli ${ }^{1}$ 2* $^{*}$, Marta Nazha ${ }^{3}$, Irene Capizzi ${ }^{3}$, Federica Neve Vigotti ${ }^{3}$, Stefania Scognamiglio ${ }^{3}$, Valentina Consiglio ${ }^{3}$, Elena Mongilardi ${ }^{4}$, Marilisa Bilocati ${ }^{5}$, Paolo Avagnina ${ }^{6}$ and Elisabetta Versino ${ }^{7}$

\begin{abstract}
Background: There is no single, gold-standard, low-protein diet (LPD) for CKD patients; the best compliance is probably obtained by personalization. This study tests the hypothesis that a multiple choice diet network allows patients to attain a good compliance level, and that, in an open-choice system, overall results are not dependent upon the specific diet, but upon the clinical characteristics of the patients.

Methods: Observational study: Three LPD options were offered to all patients with severe or rapidly progressive CKD: vegan diets supplemented with alpha-ketoacids and essential aminoacids; protein-free food in substitution of normal bread and pasta; other (traditional, vegan non supplemented and tailored). Dialysis-free follow-up and survival were analyzed by Kaplan Meier curves according to diet, comorbidity and age.

Compliance and metabolic control were estimated in 147 subjects on diet at March 2015, with recent complete data, prescribed protein intake $0.6 \mathrm{~g} / \mathrm{Kg} /$ day. Protein intake was assessed by Maroni Mitch formula.

Results: Four hundreds and forty nine patients followed a LPD in December, 2007- March, 2015 (90\% moderately restricted LPDs, $0.6 \mathrm{~g} / \mathrm{Kg} /$ day of protein, $10 \%$ at lower targets); age (median 70 (19-97)) and comorbidity (Charlson index: 7) characterized our population as being in line with the usual CKD European population. Median e-GFR at start of the diet was $20 \mathrm{~mL} / \mathrm{min}, 33.2 \%$ of the patients were diabetics. Baseline data differ significantly across diets: protein-free schemas are preferred by older, high-comorbidity patients (median age 76 years, Charlson index 8, GFR $20.5 \mathrm{~mL} / \mathrm{min}$, Proteinuria: $0.3 \mathrm{~g} /$ day), supplemented vegan diets by younger patients with lower GFR and higher proteinuria (median age 65 years, Charlson index 6, GFR $18.9 \mathrm{~mL} / \mathrm{min}$; Proteinuria: $1.2 \mathrm{~g} /$ day); other diets are chosen by an intermediate population (median age 71 years, Charlson index 6; GFR $22.5 \mathrm{~mL} / \mathrm{min}$; Proteinuria: $0.9 \mathrm{~g} /$ day); ( $p$ $<0.001$ for age, Charlson index, proteinuria, GFR). Adherence was good, only $1.1 \%$ of the patients were lost to follow-up and protein intake was at target in most of the cases with no differences among LPDs (protein intake: 0. $47(0.26-0.86) \mathrm{g} / \mathrm{Kg} /$ day). After adjustment for confounders, and/or selection of similar populations, no difference in mortality or dialysis start was observed on the different LPDs. Below the threshold of e-GFR $15 \mathrm{~mL} / \mathrm{min}, 50 \%$ of the patients remain dialysis free for at least two years.
\end{abstract}

Conclusion: A multiple choice LPD system may allow reaching good adherence, without competition among diets, and with promising results in terms of dialysis-free follow-up. The advantages with respect to a non-customized approach deserve confirmation in further comparative studies or RCTs.

Keywords: CKD, Low-protein Diet, Dialysis, Mortality

\footnotetext{
* Correspondence: gbpiccoli@yahoo.it

${ }^{1}$ Department of Clinical and Biological Sciences, University of Torino, Torino,

Italy

${ }^{2}$ Nephrologie, Centre Hospitalier Le Mans, 72000 Le Mans, France

Full list of author information is available at the end of the article
} 


\section{Background}

To date, two main reasons for reconsidering on a global scale the advantages of low protein diets, as a tool to retard dialysis in younger patients and to avoid it in elderly patients, are the limited availability of dialysis in many developing countries, and the grim prognosis of elderly patients who increasingly start dialysis in developed countries [1-3].

Low protein diets had encountered mixed fortunes in the past and the term diet, often interpreted in a reductive way, has been recently challenged in favor of "nutritional therapy" in chronic kidney disease (CKD), underlining that the approach to CKD patients should be more comprehensive, beyond the restriction of one or more aliments $[4,5]$. Indeed, nutritional therapies in CKD may be addressed to different goals: removing the cause or concause of CKD (such as obesity), reducing the workload on the remnant nephrons to slow progression, or stabilizing renal function so as to allow longer dialysis-free survival [3-6]. Furthermore, the term "nutritional therapies" switches the attention to therapeutic adherence or, using a more modern term, to concordance, a word that may substitute the older term compliance [7-10]. The concepts are similar but non identical: compliance implies the fact that the patient, "nudged or shoved", has to follow the medical advice (in this case, the "best possible diet"), while a concordant attitude is centered upon patient's preferences, and requires a flexible application, in this case, of the diet best fitting into the patient's life [11-13].

Concordance is an appealing idea, and probably the best way to manage chronic diseases; changing towards a patient-centered attitude is however time consuming, may require a dynamic approach based upon shared choices and decisions [14-16]. As stated in a recent report of the World health Organization: "patients need to be supported, not blamed (...); adherence is simultaneously influenced by several factors (...); patient-tailored interventions are required (...); systems and providers need to develop means of accurately assessing not only adherence, but also those factors that influence it." [17].

In the MDRD study, the largest, most controversial and fundamental RCT regarding diets in CKD, results are quite contradictory when analyzed according to "intention to treat" (demonstrating no advantage of being on a low protein diet) and "per protocol", stratified upon urea excretion (suggesting a significant reduction of progression in patients with lower protein intake). Such a discrepancy suggests that prescribing a diet is not enough, since patients tend to follow the diet they prefer $[18,19]$.

Many different low-protein diet (LPD) schemes have been proposed in CKD: vegan-vegetarian or omnivorous, supplemented or non-supplemented, with protein-free commercial food or without it [20]. Schematically, most authors distinguish between "moderate" protein restriction $(0.6 \mathrm{~g}$ of protein $/ \mathrm{Kg} /$ day $)$ and "very low" protein diets $(0.3 \mathrm{~g} / \mathrm{Kg} /$ day); each of them may be proposed by different schemas, with or without the allowance of unrestricted meals [21-27].

Flexible, personalized, holistic approaches are not easily analyzed, since by their own nature they tend to escape from the rigidity of RCTs [28-32]. Randomization to different approaches (tailored versus standardized) could highlight differences, but may be hardly feasible in single centers, in which the option of personalization is often a part of the approach to the continuum of CKD care. In such a context, observational studies are more likely to provide information on feasibility and side effects, and may overcome some of the limits of RCTs, mainly the inclusion of populations that differ from the standard ones encountered in daily practice $[32,33]$.

Consequently, adherence to therapy and incidence of drop-out may represent important, albeit indirect, measures of success, since we may expect that multiple-choice systems may allow easier identification of a concordant strategy.

Hence, the present study was undertaken to test the hypothesis that a multiple choice diet system in which patients are free to choose (and change) the most suitable LPD from among several options, could allow an overall good therapeutic adherence to LPDs. We analyzed a large single-center cohort of on-diet patients (449 patients, 847 patient-years of observation, in which diets, mainly with a moderate protein restriction, and controls follow a personalized schedule of prescriptions and check-ups, adapted to the various clinical situations [20, 33-36].

\section{Methods}

\section{Study setting; patient selection and inclusion criteria}

The study was carried out at the out-patient Nephrology Unit of the San Luigi Hospital, University of Torino, Italy. The Unit started its activity on $1^{\text {st }}$ December, 2007, and by $31^{\text {st }}$ March, 2015, over 4000 patients had been evaluated.

CKD was defined according to the usual definitions of the K/DOQI clinical practice guidelines; e-GFR was assessed by the CKD-EPI equation, and compliance to the protein intake by the Maroni-Mitch formula [37-39].

In the study setting, an LPD is routinely proposed by the nephrologist to all pre-dialysis patients with CKD stages 4-5, and to those with rapid progression of CKD stage 3 and/or with refractory nephrotic syndrome, in the absence of contraindications, as elsewhere described more in detail [33].

\section{Diets and controls}

Over time, the approach to LPDs shifted from the proposal of two main LPDs $(0.6 \mathrm{~g} / \mathrm{Kg} /$ day: vegan-vegetarian supplemented with alpha-ketoacids and aminoacids (LPD-AK) and with protein-free commercial food (LPD$\mathrm{PFF})$ ), which were eventually merged into one very-low 
protein diet (vLPD), to a more integrated choice including different combinations of the previous diets and vegan non-supplemented diets [20,33-36] (Table 1).

All diets share a simplified and flexible approach aimed at facilitating integration into daily life. The LPD prescription is qualitative: it is based on allowed and forbidden foods, with 1-3 unrestricted meals per week (depending on the patients' preferences and kidney function) [33]. The first diet prescribed in our Unit is a moderately restricted diet (on average $0.6 \mathrm{~g} / \mathrm{Kg} /$ day of protein) and only after a successful trial, in selected cases a 0.3 diet is prescribed.

In our region, both protein-free food and Ketosteril or Alfa-kappa are provided free of charge (maximum expenditure for protein-free food: 120 euro per month).

Daily energy intake is aimed at $30-35 \mathrm{kcal} / \mathrm{Kg} / \mathrm{day}$; caloric intake is calculated on the basis of a diet journal that is kept for 1-3 weeks. In elderly patients a caloric intake of $25-30 \mathrm{kcal} / \mathrm{Kg} /$ day was considered acceptable, provided that weight, albumin and bioimpedence measures remained stable.

Supplementation with calcium, vitamin D, folic acid, vitamin B12, iron and erythropoietin is tailored according to blood levels on the basis of the usual indications. Biochemical exams and routine visits are scheduled every 1-2 months in stable subjects and up to once a week for patients with severe metabolic derangements or when
GFR drops to below 7-10 $\mathrm{mL} / \mathrm{min}$. Dialysis start is decided on the basis of the clinical picture (including symptoms such as weight loss, nausea, malnutrition, restless leg syndrome, poorly controlled hypertension); GFR, urea levels, water and acid-base balance, calcium-phosphatePTH balance, anemia and albuminemia are taken into account in the overall evaluation of the patient.

The simplified diets were originally designed and prescribed by the nephrologist; between 2007 and 2012, consultation with a dietitian was available only for complex cases (overweight, underweight; specific situations such as celiac disease or food allergy). Since 2013, a part-time dietitian was enrolled in the team, thus ensuring systematic counseling for all on-diet patients; her support leaded also to an increase in personalized dialysis schedules (LPD-Other).

\section{Biochemical data}

Biochemical parameters are always assessed in the patient's laboratory of choice, and for about $70 \%$ of subjects this means the General Laboratory of our hospital. Regularly controlled biochemical data included serum creatinine $(\mathrm{mg} / \mathrm{dL}), \mathrm{BUN}(\mathrm{mg} / \mathrm{dL}), \mathrm{GFR}(\mathrm{CKD}-\mathrm{EPI})$, proteinuria (g/day); $\mathrm{HCO} 3(\mathrm{mmol} / \mathrm{L})$, albumin $(\mathrm{g} / \mathrm{dL})$, parathyroid hormone $(\mathrm{PTH}, \mathrm{pg} / \mathrm{mL}$ ), protein intake (Maroni Mitch formula [39]).

Table 1 The various low-protein diets offered in our Unit and included in this study

\begin{tabular}{lll}
\hline Type of diet & $\begin{array}{l}\text { Protein restriction } \\
\text { (g/Kg of body weight per day) }\end{array}$ & Main features \\
\hline "Traditional" & $\begin{array}{l}0.6-0.8 \mathrm{~g} / \mathrm{Kg} / \text { day; mixed protein } \\
\text { (animal and plant derived) }\end{array}$ & $\begin{array}{l}\text { Modulated upon quantity of usual food; mainly } \\
\text { based on the traditional Italian regional cuisines. }\end{array}$ \\
Vegan & $\begin{array}{l}0.6-0.8 \mathrm{~g} / \mathrm{Kg} / \text { day; vegetable } \\
\text { protein }\end{array}$ & $\begin{array}{l}\text { Protein intake in unrestricted vegan diets is on } \\
\text { the average } 0.7-0.9 \mathrm{~g} / \mathrm{Kg} / \text { day; due to the } \\
\text { different bioavailability, a } 0.7 \text { diet roughly } \\
\text { corresponds to a } 0.6 \text { mixed protein diet }\end{array}$
\end{tabular}

$\begin{array}{ll}\text { Vegan } & 0.6 \mathrm{~g} / \mathrm{Kg} / \text { day; vegetable protein, } \\ \text { supplemented } & \text { supplemented with amino- and } \\ \text { (moderate } & \text { keto-acids (Alfa-kappa or } \\ \text { restriction) } & \text { Ketosteril) }\end{array}$

Protein-free $\quad 0.6 \mathrm{~g} / \mathrm{Kg} / \mathrm{day}$; mixed protein food

Very low- $\quad 0.3 \mathrm{~g} / \mathrm{Kg} /$ day; vegetable protein protein supple- only, supplemented with Alfamented vegan kappa or Ketosteril, with proteindiet free food

Tailored Usually $0.6 \mathrm{~g} / \mathrm{Kg} /$ day, vegetable solutions or mixed
Based upon forbidden (animal origin) and allowed (all other) food. Animal-derived food is allowed in unrestricted meals. Supplementation with Alfakappa or Ketosteril pills is tailored upon nutritional status and clinical situation (1:8-1:10 Kg BW)

Protein-free pasta, bread and other carbohydrates substituting for the usual bread, pasta or rice.

This diet is also based upon forbidden (animal origin) and allowed (all other) food. Animalderived food is allowed only in "free meals" (usually no more than 1 per week) Supplementation with Alfa-kappa or Ketosteril pills is higher (1:5 $\mathrm{Kg} \mathrm{BW}$ ). Carbohydrates are mainly protein-free.

These solutions employ different combinations of protein-free food, vegan diets and supplementation.

\section{Notes}

Often corresponds to what elderly patients already follow, in particular if they cook their own food from raw ingredients.

This diet is based upon the integration of cereals and legumes at each meal, thus ensuring complementarity in amino acids. The 1-3 unrestricted meals per week are also crucial for this goal.

The supplements of amino- and ketoacids ensure protein complementarity without need to choose among plant derived food.

Since carbohydrates are the basis of the Mediterranean cuisine, their substitution allows subjects to easily reach a $0.6 \mathrm{~g} / \mathrm{Kg} / \mathrm{BW}$ diet

This diet merges the concepts of vegan supplemented and protein-free food. It is demanding and requires compliance to the high number of pills employed in supplementation. It is not prescribed as a "first line" diet.

The main reason for prescribing these diets is to take into account patients' needs or preferences: an example: alternating vegansupplemented meal and protein-free food. 
For the sake of uniformity in the dosage methods, only the results of tests performed in the General Laboratory of the hospital in the last period of study were included in the analysis of compliance. Furthermore, we standardized our $24 \mathrm{~h}$ urine collection (at least $48 \mathrm{~h}$ from an unrestricted meal) only in 2014-2015; therefore, this analysis was carried out in prevalent patients at March $31^{\text {st }}, 2015$, considering the data available in our laboratory, updated within 3 months (147 cases).

\section{Statistical analysis}

A descriptive analysis was performed as appropriate (median and range for non-parametric data, mean and standard deviation for parametric distribution), ANOVA, KruskalWallis, Mann-Whitney, and $t$-test were performed according to standard indications for continuous variables, while risks, rates and proportions were compared using Chisquare and Fisher's exact test.

Survival analysis was performed according to Kaplan Meier also in order to identify the relevant covariates to be entered into a multivariate analysis. The following covariates were analyzed: type of diet (intention to treat); moderate protein restriction; vegan supplemented; with protein-free food; other diets.

Age was dichotomized at 65 years, or analyzed with the following strata $(\langle 64 ; 65-75 ;\rangle=75)$; comorbidity was weighted by the Charlson index (dichotomized at 7) [40]. Significance of the differences was tested by the log-rank test and Wilcoxon test.

Three outcomes were considered: dialysis (renal death), mortality, combined outcome (death or dialysis). The beginning of the observation period was either the start of the diet or referral to the Unit for patients who were already on LPDs. The end of observation was the end of the diet. A separate analysis was performed starting with the observation at the first recording of GFR $<10$ or $<15 \mathrm{~mL} / \mathrm{min}$ (considered "late-conventional" and "early" start of dialysis, respectively).

\section{Multivariate and stratified analysis}

Survival analysis: Cox analysis was performed considering the following covariates: Charlson index (dichotomized at 7 ); type of diet (first diet, following an intention to treat analysis; due to the heterogeneity of the "other" diets, we included only the two main ones: LPD-AK and LPD-PFF in the analysis); GFR (dichotomized at $30 \mathrm{~mL} / \mathrm{min}$ ) and proteinuria (dichotomized at $1 \mathrm{~g} /$ day) at the start of the diet. Age, which is included in the Charlson index, was not entered in the model due to co-linearity.

For the analysis of dialysis start, to account for the attrition bias of death versus the risk of starting dialysis (competitive mortality), we selected a homogeneous group of subjects with regard to age, comorbidity, and kidney function (age $>=65-<80$ years; Charlson index $>$
$=5-<12$, baseline proteinuria $<3 \mathrm{~g} /$ day, initial GFR $>$ $=15-<30 \mathrm{~mL} / \mathrm{min})$. Diet, Charlson index and GFR were entered into the Cox analysis.

\section{Ethical issues}

Informed consent was obtained for anonymous management of the clinical data. Individual consent for publication was not needed for this study, dealing with overall data and not with single cases.

The observational study design (PROTEREne: PROTEin REductio to protect the REins) based on standard clinical practice, that includes patients with severe CKD, was approved by the Ethics Committee of the San Luigi Hospital, University of Torino (Delibera 22, 18 January 2013, protocol 000037).

\section{Results}

\section{Baseline data}

Patients who opted for different diets have different baseline characteristics (Table 2). Patients who choose a low protein vegan supplemented diet (LPD-KA) are significantly younger, with lower comorbidity and higher prevalence of glomerulonephritis, nephrotic proteinuria and severely impaired GFR, as compared to patients who select an LPD based upon the substitution of the usual carbohydrates with protein-free food (LPD-PFF). The latter are significantly older, their kidney diseases are more often linked to cardiovascular impairment, and glomerulonephritides are seldom encountered. Followers of the "other" options, more recently implemented in the system, including vegan or Mediterranean diets, are in the intermediate age and comorbidity group (Table 2 ).

\section{Main outcomes}

The main outcomes are unevenly distributed, related to the first diet that was chosen (Table 3). Half of the patients are still on an LPD at the time of this study (225 patients); thanks to-choose the flexible approach only few patients discontinued the diet or were lost to followup (5 cases, 1.1\%).

As expected by the baseline distribution, death is the most common cause of discontinuation on LPD-PFF (patients are about 10 years older and with higher comorbidity); dialysis start is the most common cause of discontinuation in patients who start on an LPD-KA, in keeping with a longer life-expectancy of these younger patients, one third of whom are affected by glomerular or systemic diseases. The heterogeneous group of patients who chose other schedules lies between these first two as for age and comorbidity; however, serum creatinine is lower and e-GFR higher in this subset of cases, reflecting a slow and cautious integration of the new LPD approaches in the context of a well established use of the previous two schemes (LPD-KA and LPD-PFF). 
Table 2 Baseline characteristics of the population, on the basis of the first diet

\begin{tabular}{|c|c|c|c|c|c|}
\hline First diet & Vegan supplemented & With protein- free food & Other & All cases & p Among groups \\
\hline$n$ & 215 & 159 & 75 & 449 & \\
\hline Males (\%) & $144(67.0 \%)$ & $98(61.6 \%)$ & $34(45.3 \%)$ & $276(61.5 \%)$ & 0.004 \\
\hline Females (\%) & $71(33.0 \%)$ & $61(38.4 \%)$ & $41(54.7 \%)$ & $173(38.5 \%)$ & \\
\hline Age: median (min-max) & $65(19-86)$ & $76(26-97)$ & $71(23-88)$ & 70 (19-97) & $<0.001$ \\
\hline Age over 65 (\%) & $100(46.5 \%)$ & $132(83 \%)$ & $42(56 \%)$ & $274(61 \%)$ & $<0.001$ \\
\hline Age over 80 (\%) & $15(7.0 \%)$ & $44(27.7 \%)$ & $14(18.7 \%)$ & $73(16.3 \%)$ & $<0.001$ \\
\hline Charlson: median (min-max) & $6(2-12)$ & $8(2-13)$ & $6(2-12)$ & $7(2-13)$ & $<0.001$ \\
\hline Charlson > =7 (\%) & 91 (42.3\%) & $118(74.2 \%)$ & 37 (49.3\%) & $246(54.8 \%)$ & $<0.001$ \\
\hline Charlson > =10 (\%) & 17 (7.9\%) & $42(26.4 \%)$ & $12(16.0 \%)$ & $71(15.8 \%)$ & $<0.001$ \\
\hline Diabetes (\%) & $59(27.4 \%)$ & $70(44 \%)$ & $20(26.7 \%)$ & 149 (33.2\%) & 0.001 \\
\hline Cardiopathy (\%) & 79 (36.7\%) & $100(62.9 \%)$ & $29(38.7 \%)$ & $208(46.3 \%)$ & $<0.001$ \\
\hline Neoplasia (\%) & $41(19.1 \%)$ & $33(20.8 \%)$ & $23(30.7 \%)$ & $97(21.6 \%)$ & 0.104 \\
\hline sCreatinine (mg/dL) median (min-max) & $3.05(0.6-16)$ & $2.65(1.0-7)$ & $2.49(0.6-6.7)$ & $2.8(0.6-16)$ & $<0.001$ \\
\hline eGFR-EPI (mL/min) median (min-max) & $18.9(3-126)$ & $20.5(6.6-73)$ & $22.5(5.7-127)$ & $20.0(3-127)$ & 0.014 \\
\hline GFR <15 mL/min at enrolment $\mathrm{n}(\%)$ & $80(37.6 \%)$ & $32(20.1 \%)$ & $13(17.3 \%)$ & $125(28 \%)$ & $<0.001$ \\
\hline GFR <10 mL/min at enrolment $\mathrm{n}(\%)$ & $29(13.6 \%)$ & $10(6.3 \%)$ & $5(6.7 \%)$ & $44(9.8 \%)$ & 0.038 \\
\hline $\begin{array}{l}\text { Proteinuria (g/day) } \\
\text { median (min-max) }\end{array}$ & $1.2(0.1-10)$ & $0.3(0.1-7)$ & $0.9(0.1-11)$ & $0.8(0.1-11)$ & $<0.001$ \\
\hline Proteinuria > = $1 \mathrm{~g} /$ day (\%) & $125(58.7 \%)$ & $41(26.1 \%)$ & $36(48.0 \%)$ & $202(45.4 \%)$ & $<0.001$ \\
\hline Proteinuria > = 3 g/day (\%) & $50(23.5 \%)$ & $18(11.5 \%)$ & $14(18.7 \%)$ & $82(18.4 \%)$ & 0.013 \\
\hline Glomerulonephritis-systemic disease (\%) & $67(31.2 \%)$ & $12(7.5 \%)$ & $16(21.3 \%)$ & $95(21.2 \%)$ & $<0.001$ \\
\hline Nephroangiosclerosis and/or diabetes (\%) & $100(46.5 \%)$ & $128(80.5 \%)$ & 37 (49.3\%) & $265(59.0 \%)$ & $<0.001$ \\
\hline ADPKD (\%) & $13(6.0 \%)$ & $4(2.5 \%)$ & 7 (9.3\%) & 24 (5.3\%) & 0.079 \\
\hline
\end{tabular}

Charlson Charlson's comorbidity index, E-GFR EPI GFR according to the CKD-EPI equation, ADPKD autosomal dominant polycystic kidney disease

The attrition bias due to the competition between mortality and dialysis start is highlighted in Fig. 1: the patients with higher mortality (higher Charlson index, older age) have a lower risk of dialysis start. Accordingly, the two main diets, LPD-PFF and LPD-KA, have opposite patterns with respect to mortality (higher in the former) and dialysis (higher in the latter).

Cardiovascular diseases are the most common cause of death, as expected by the comorbidity burden (patients who died: median Charlson index at start of the diet: 9) (Table 4).
Patients who start dialysis are significantly younger and with less comorbidity than those who die (Tables 4 and 5). Of note, only 3 patients started unplanned dialysis (in 1 case because of the rupture of a polycystic kidney and in 2 because of fluid overload; the two latter subjects already had an AV fistula and dialysis was started on the day of a planned clinical visit) (Table 5).

\section{Patient survival: Cox analysis}

According to Cox analysis, which was performed considering only the two most frequent diets with comparable

Table 3 Main outcomes: distribution based on the first diet

\begin{tabular}{|c|c|c|c|c|c|}
\hline First diet & Vegan supplemented & With protein-free food & Other & All cases & $p$ Among groups \\
\hline Continues n (\%) & $86(40.0 \%)$ & $81(50.9 \%)$ & $58(77.3 \%)$ & $225(50.1 \%)$ & $<0.001$ \\
\hline Discontinued n(\%) & $6(2.8 \%)$ & $2(1.3 \%)$ & 0 & $8(1.8 \%)$ & \\
\hline Transferred n (\%) & $4(1.9 \%)$ & $1(0.6 \%)$ & $1(1.3 \%)$ & $6(1.3 \%)$ & \\
\hline Lost to follow-up n (\%) & $1(0.5 \%)$ & $4(2.5 \%)$ & 0 & $5(1.1 \%)$ & \\
\hline On dialysis n (\%) & 83 (38.6\%) & $12(7.5 \%)$ & $10(13.3 \%)$ & $105(23.4 \%)$ & \\
\hline Dead n (\%) & 35 (16.3\%) & $59(37.1 \%)$ & $6(8.0 \%)$ & $100(22.3 \%)$ & \\
\hline Overall follow-up (years) & 375.67 & 335 & 136.5 & 847.17 & 0.124 \\
\hline
\end{tabular}

9 further deaths were recorded in the first year after discontinuation of the diet; all occurred on dialysis (on further 94.4 years of observation) 


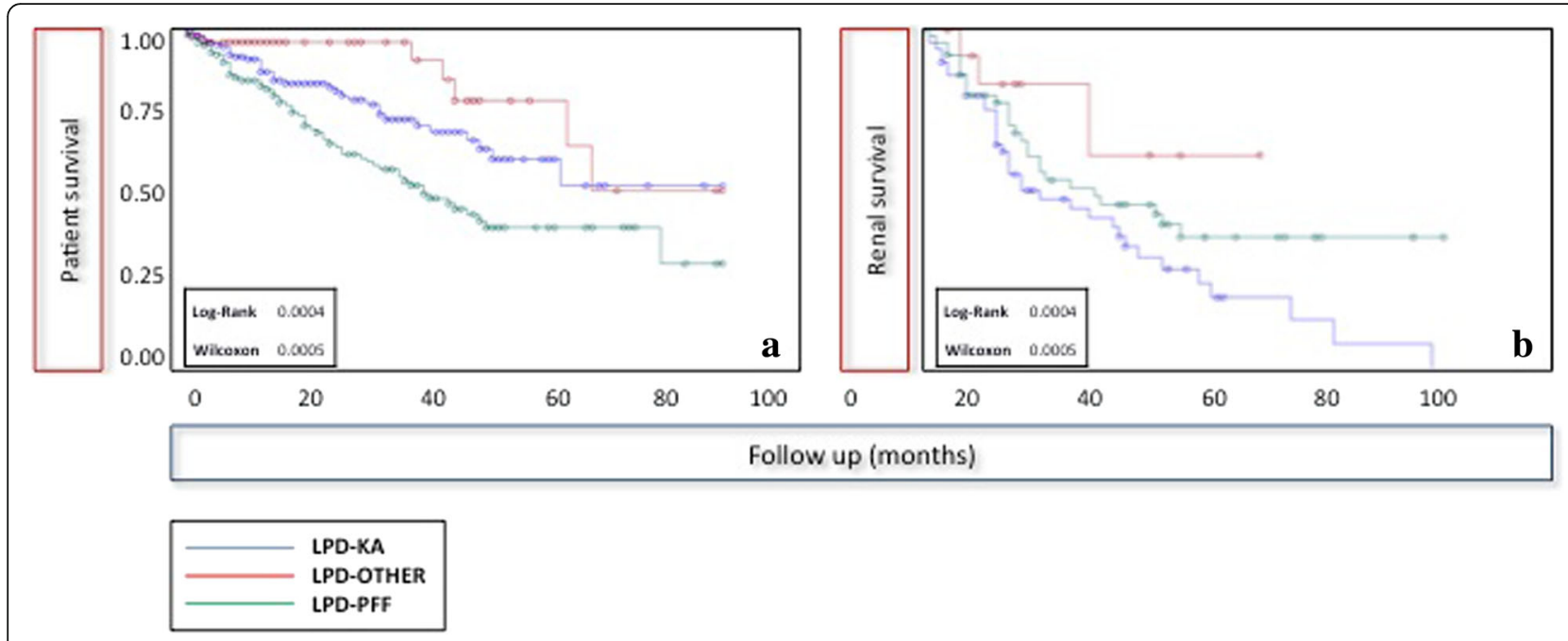

Fig. 1 Patient survival and "renal survival" according to the diet chosen

follow-up (LPD-KA and LPD-PFF, both with over 300 patient-years of observation), survival is significantly affected by Charlson index, but neither the diet nor kidney function or proteinuria at baseline retained a significant effect (Table 6).
Dialysis start: the effect of the diet in selected subsets of homogeneous cases

Table 7 summarizes the analysis performed on a selected population (age $>=65$ and $<80$ years; Charlson index $>4$ and $<12$, baseline proteinuria $<3$ g/day and

Table 4 Characteristics of the patients who died, stratified on the basis of the first diet

\begin{tabular}{|c|c|c|c|c|c|}
\hline First diet & Vegan supplemented & With protein- free food & Other & All cases & p Among groups \\
\hline$n$ & 35 & 59 & 6 & 100 & \\
\hline Males/Females (\%) & $\begin{array}{l}29(82.9 \%) \\
6(17.1 \%)\end{array}$ & $\begin{array}{l}38(64.4 \%) \\
21(35.6 \%)\end{array}$ & $\begin{array}{l}5(83.3 \%) \\
1(16.7 \%)\end{array}$ & $\begin{array}{l}72(72.0 \%) \\
28(28.0 \%)\end{array}$ & 0.128 \\
\hline Age at start of the diet median (min-max) & 71 & 78 & 70 & 74 & 0.003 \\
\hline Charlson index median (min max) & $9(6-12)$ & $9(5-12)$ & $8(2-11)$ & $9(2-12)$ & 0.794 \\
\hline Charlson > =7 (\%) & $30(85.7 \%)$ & $53(89.8 \%)$ & $4(66.7 \%)$ & 87 (87.0\%) & 0.264 \\
\hline Charlson > =10 (\%) & $9(25.7 \%)$ & 19 (32.2\%) & $2(33.3 \%)$ & $30(30.0 \%)$ & 0.789 \\
\hline Diabetes (\%) & $17(48.6 \%)$ & $30(50.8 \%)$ & $3(50.0 \%)$ & $50(50.0 \%)$ & 0.977 \\
\hline Cardiopathy (\%) & $27(77.1 \%)$ & $49(83.1 \%)$ & $4(66.7 \%)$ & $80(80.0 \%)$ & 0.552 \\
\hline Neoplasia (\%) & $9(25.7 \%)$ & $12(20.3 \%)$ & $1(16.7 \%)$ & $22(22.0 \%)$ & 0.788 \\
\hline s Creatinine (mg/dL) median, (min-max) & $3.01 .6-5$ & $2.51 .1-5.9$ & $3.652 .6-4.3$ & $2.901 .1-5.9$ & 0.002 \\
\hline eGFR-EPI (mL/min) median, (min-max) & $18.910 .9-44.5$ & $20.87 .7-73.1$ & $16.010 .3-17.7$ & $20.07 .7-73.1$ & 0.022 \\
\hline Proteinuria (g/day) median, (min-max) & $0.50 .1-4.6$ & $0.20 .1-6.3$ & $0.20 .1-1.0$ & $0.350 .1-6.3$ & 0.111 \\
\hline Proteinuria > = $1 \mathrm{~g} /$ day (\%) & $12(34.3 \%)$ & $13(22.8 \%)$ & $1(16.7 \%)$ & $26(26.0 \%)$ & 0.410 \\
\hline Glomerulonephritis-systemic disease (\%) & $3(8.6 \%)$ & $1(1.7 \%)$ & 0 & $4(4 \%)$ & 0.226 \\
\hline Nephroangiosclerosis and/or diabetes (\%) & $30(85.7 \%)$ & $52(88.1 \%)$ & $4(66.7 \%)$ & $86(86 \%)$ & 0.352 \\
\hline \multicolumn{6}{|l|}{ Main causes of death } \\
\hline Cardiovascular (\%) & $16(45.7 \%)$ & $29(49.1 \%)$ & $2(33.3 \%)$ & $47(47 \%)$ & 0.590 \\
\hline Neoplasia (\%) & $4(11.4 \%)$ & $3(5.1 \%)$ & $1(16.7 \%)$ & $8(8 \%)$ & \\
\hline Lung disease (\%) & $1(2.8 \%)$ & $4(6.7 \%)$ & 0 & $5(5 \%)$ & \\
\hline Infection (\%) & $4(11.4 \%)$ & $5(8.5 \%)$ & 0 & $9(9 \%)$ & \\
\hline Other (\%) & $6(17.1 \%)$ & $5(8.5 \%)$ & 2 (33.3\%) & $13(13 \%)$ & \\
\hline Unknown (\%) & 4 (11.4\%) & $13(22.1 \%)$ & 1 (16.7\%) & $18(18 \%)$ & \\
\hline
\end{tabular}


Table 5 Characteristics of the patients who started dialysis (listed on the basis of the first diet)

\begin{tabular}{|c|c|c|c|c|c|}
\hline First diet & Vegan supplemented & With protein- free food & Other & All cases & p Among groups \\
\hline$n$ & 83 & 12 & 10 & 105 & \\
\hline Males/Females (\%) & $\begin{array}{l}52(62.7 \%) \\
31(37.3 \%)\end{array}$ & $\begin{array}{l}8 \text { (66.7\%) } \\
4(33.3 \%)\end{array}$ & $\begin{array}{l}4(40.0 \%) \\
6(60.0 \%)\end{array}$ & $\begin{array}{l}64(61.0 \%) \\
41(39.0 \%)\end{array}$ & 0.348 \\
\hline Age at start of diet: median (min max) & $63(23-86)$ & $72(59-86)$ & $69.5(29-83)$ & $64(23-86)$ & 0.009 \\
\hline Age over 65 (\%) & $32(38.6 \%)$ & $9(75.0 \%)$ & $6(60.0 \%)$ & $47(44.8 \%)$ & 0.036 \\
\hline Age over 80 (\%) & $4(4.8 \%)$ & $2(16.7 \%)$ & $1(10.0 \%)$ & $7(6.7 \%)$ & 0.278 \\
\hline Charlson index median (min max) & $6(2-11)$ & $7.5(5-12)$ & $8(4-10)$ & $6(2-12)$ & 0.001 \\
\hline Charlson > =7 (\%) & $30(36.1 \%)$ & $9(75.0 \%)$ & $8(80.0 \%)$ & $47(44.8 \%)$ & 0.003 \\
\hline Charlson > =10 (\%) & $5(6.0 \%)$ & $3(25.0 \%)$ & $1(10.0 \%)$ & $9(8.6 \%)$ & 0.089 \\
\hline Diabetes (\%) & $23(27.7 \%)$ & $7(58.3 \%)$ & $4(40.0 \%)$ & $34(32.4 \%)$ & 0.091 \\
\hline Cardiopathy (\%) & $26(31.3 \%)$ & $6(50.0 \%)$ & $6(60.0 \%)$ & $38(36.2 \%)$ & 0.117 \\
\hline Neoplasia (\%) & $16(19.3 \%)$ & $2(16.7 \%)$ & $6(60.0 \%)$ & $24(22.9 \%)$ & 0.013 \\
\hline s Creatinine (mg/dL) median, (min-max) & $4.5(1.5-16.0)$ & $3.3(2.3-6.4)$ & $3.6(2.5-6.7)$ & $4.2(1.5-16.0)$ & 0.492 \\
\hline eGFR-EPI (mL/min) median, (min-max) & $12.8(3.0-44.6)$ & $16.2(7.7-25.5)$ & $15.1(5.7-19.7)$ & $13.2(3.0-44.6)$ & 0.885 \\
\hline Proteinuria (g/day) median, (min-max) & $1.5(0.1-9)$ & $1.4(0.7-5.7)$ & $3.3(0.1-11)$ & $1.5(0.1-11)$ & 0.407 \\
\hline Proteinuria > =1 g/day (\%) & $55(67.9 \%)$ & $8(66.7 \%)$ & $7(70.0 \%)$ & $70(68.0 \%)$ & 0.986 \\
\hline Proteinuria > =3 g/day (\%) & $21(25.9 \%)$ & $4(33.3 \%)$ & $5(50.0 \%)$ & $30(29.1 \%)$ & 0.270 \\
\hline Glomerulonephritis-systemic disease (\%) & $26(31.3 \%)$ & $2(16.7 \%)$ & $2(20.0 \%)$ & $30(28.6 \%)$ & 0.472 \\
\hline Nephroangiosclerosis and/or diabetes (\%) & $37(44.6 \%)$ & $10(83.3 \%)$ & $5(50.0 \%)$ & $52(49.5 \%)$ & 0.043 \\
\hline ADPKD (\%) & $7(8.4 \%)$ & $0(0.0 \%)$ & $2(20.0 \%)$ & $9(8.6 \%)$ & 0.247 \\
\hline Type of dialysis (\% HD) & $71(85.5 \%)$ & $10(83.3 \%)$ & $10(100 \%)$ & $91(86.6 \%)$ & 0.457 \\
\hline dialysis in emergency $\mathrm{n}(\%)$ & $3(3.6 \%)$ & 0 & 0 & $3(2.8 \%)$ & 0.630 \\
\hline
\end{tabular}

GFR at start between 15 and $30 \mathrm{~mL} / \mathrm{min})$, chosen to try to overcome the attrition bias of mortality, given the baseline differences by self-allocation of different patients to different diets (Table 2). According to this analysis, there is no difference according to LPD, and only proteinuria retains a significant effect on renal survival (Fig. 2: outcome ESRD or death in the selected population).

\section{Compliance and metabolic control}

Table 8 reports the main biochemical data in a prevalent subset of the on-diet population (on a $0.6 \mathrm{~g} / \mathrm{Kg} /$ day diet)

Table 6 Crude and adjusted HRs of mortality, by diet, Charlson index, proteinuria, and GFR (Cox analysis) (LPD-KA and LPD-PFF)

\begin{tabular}{|c|c|c|c|c|c|}
\hline & $n / N$ & Crude RR (95\% Cls) & $p$ value & Adjusted HR (95\% Cls) & $p$ value \\
\hline \multicolumn{6}{|l|}{ Diet } \\
\hline LPD-KA & $37 / 215$ & $1(-)$ & $<0.0001$ & $1(-)$ & 0.5264 \\
\hline LPD-PFF & $59 / 159$ & $2.16(1.51-3.08)$ & & $1.15(0.75-1.75)$ & \\
\hline Charlson index & & & & & $<0.0001$ \\
\hline$<7$ & $12 / 165$ & $1(-)$ & $<0.0001$ & $1(-)$ & \\
\hline$\geq 7$ & $84 / 209$ & $5.53(3.13-9.77)$ & & $6.11(3.28-11.36)$ & \\
\hline \multicolumn{6}{|l|}{ Proteinuria } \\
\hline (g/day) & & & $<0.0001$ & & 0.2107 \\
\hline$<1$ & $69 / 207$ & $1(-)$ & & $1(-)$ & \\
\hline$\geq 1$ & $27 / 167$ & $0.49(0.33-0.72)$ & & $0.75(0.48-1.18)$ & \\
\hline GFR (ml/m) & & & & & 0.2425 \\
\hline$<30$ & $78 / 291$ & $1(-)$ & 0.3436 & $1(-)$ & \\
\hline$\geq 30$ & $18 / 83$ & $0.81(0.72-1.27)$ & & $0.74(0.44-1.23)$ & \\
\hline
\end{tabular}


Table 7 Crude and adjusted HRs of dialysis start by main diet (LPD-KA, LPD-PFF), Charlson index, proteinuria, and GFR (Cox analysis) in the population: age $>=65-<80$ years; Charlson index $>=5<12$; proteinuria $<3 \mathrm{~g} /$ day GFR at start $>=15<30 \mathrm{~mL} / \mathrm{min}$

\begin{tabular}{|c|c|c|c|c|c|}
\hline & $n / N$ & Crude RR (95\% Cls) & $P$ value & Adjusted HR (95\% Cls) & $P$ value \\
\hline \multicolumn{6}{|l|}{ Diet } \\
\hline LPD-KA & $6 / 32$ & $(1-)$ & 0.19 & $(1-)$ & 0.2326 \\
\hline LPD-PFF & $4 / 46$ & $0.46(0.14-1.51)$ & & $0.43(0.11-1.72)$ & \\
\hline \multicolumn{6}{|c|}{ Charlson index } \\
\hline$<7$ & $2 / 25$ & $(1-)$ & 0.38 & $(1-)$ & 0.7511 \\
\hline$\geq 7$ & $8 / 53$ & $1.89(0.43-8.25)$ & & $1.31(0.25-6.93)$ & \\
\hline \multicolumn{6}{|c|}{ Proteinuria (g/day) } \\
\hline$<1$ & $3 / 55$ & $(1-)$ & 0.002 & $(1-)$ & 0.0303 \\
\hline$\geq 1$ & $7 / 23$ & $5.58(1.58-19.71)$ & & $5.13(1.17-22.55)$ & \\
\hline
\end{tabular}

$R R$ Relative risk, $H R$ Hazard ratio

as of March $31^{\text {st }}$, 2015, who underwent metabolic and renal functional assessment within three months in the general laboratory of our hospital (147 patients, out of 209 prevalent patients on a $0.6 \mathrm{~g} / \mathrm{Kg} /$ day of protein diet on follow-up at the same date). The general characteristics of this subset are as expected from our enrollment criteria: median e-GFR below $30 \mathrm{~mL} / \mathrm{min}$, about one fourth of the patients with e-GFR $<15 \mathrm{~mL} / \mathrm{min}$. Compliance to the diet $(0.6 \mathrm{~g} / \mathrm{Kg} /$ day $)$ assessed on a $24-\mathrm{h}$ urine collection was very good (median $0.47 \mathrm{~g} / \mathrm{Kg} /$ day, performed at least $48 \mathrm{~h}$ after the last unrestricted meal) and more than half of the patients were slightly below the prescribed intake. Moreover, serum albumin was within the normal range in most cases, and the 11 patients with serum albumin $<3 \mathrm{~g} / \mathrm{dL}$ were characterized by low Charlson index (median 4, range 2-9) and high proteinuria (median 5.6, min-max: 1.1-10.9 g/day), suggesting

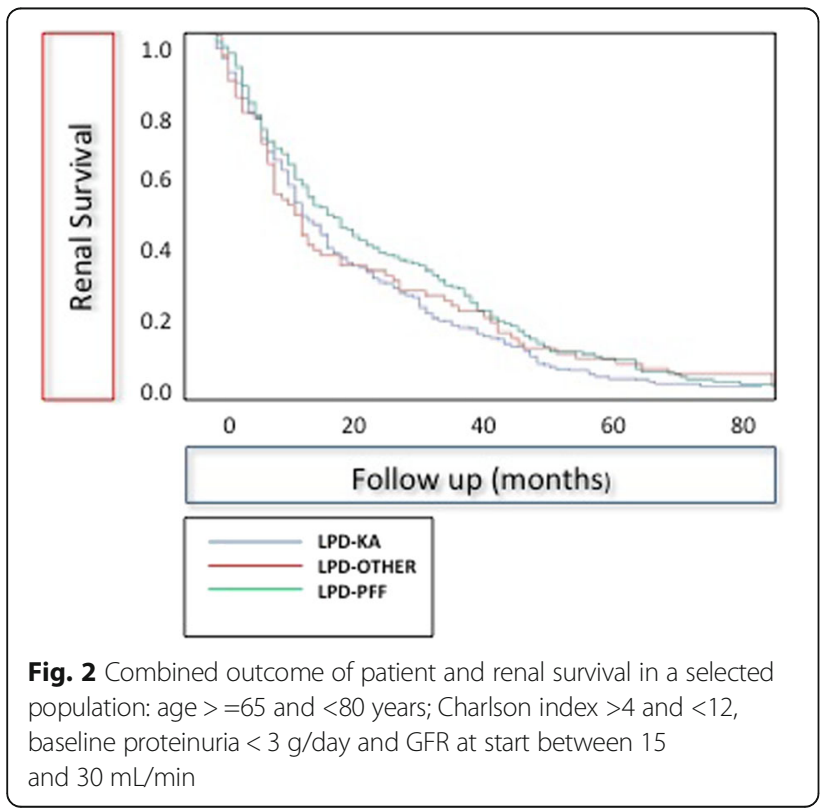

that this was most likely an effect of the kidney disease and not of malnutrition. Furthermore, parathyroid hormone and bicarbonate levels were on target in most cases, and only 5 patients ( 3 of whom had severe cardiac disease and high need for diuretics) had a BUN above $100 \mathrm{mg} / \mathrm{dL}$.

\section{Discussion}

The main point of interest in our study regards the multiple-choice approach developed, which indirectly demonstrated the relevance of patient's preferences: when patients are given various options, different categories of individuals choose different diets (Tables 1 and 2). These data are in keeping with previous studies by our group that suggested, on a smaller scale, that LPD choice reflected the patients' characteristics: elderly patients, less willing to change their dietary habits, prefer diets based upon the substitution of regular carbohydrates (mainly bread and pasta in Italy, which contain $11-12 \%$ of protein) with protein-free food, while younger patients prefer a simplified scheme of supplemented vegan/vegetarian diets, which are more compatible with their "social life" [20, 25, 33]. Other experts report similar data on diets based upon protein-free food, suggesting that such an option, which is free of charge in our country, should also be considered in other settings [14-16, 23, 26, 41, 42].

While only larger multicenter studies, comparing (and eventually randomizing) different approaches to protein restriction in CKD may definitely highlight the specific features, advantages and draw-backs of a multiplechoice dietary approach, flexibility may be the reason why only a minority of the patients discontinued LPDs $(1.8 \%)$, or was lost to follow-up (1.1\%), while about $10 \%$ of the subjects changed at least one diet over time (Table 3). Likewise, it may offer an indirect explanation to the good compliance and metabolic control observed: an up-date involving a sample of 147 on-diet prevalent stable subjects with complete data showed that protein 
Table 8 Compliance and main biochemical data at the (last updating): 147 on-diet patients who underwent complete biochemical profiling by March 31 32015 (with a complete biochemical profile performed at the san Luigi General Laboratory)

\begin{tabular}{|c|c|c|c|c|c|c|}
\hline Diet history & LPD-KA only & LPD-PFF only & Other only & $\begin{array}{l}\text { More than } \\
\text { one diet }\end{array}$ & All patients & $\begin{array}{l}\text { p Among } \\
\text { groups }\end{array}$ \\
\hline$n$ & 54 & 46 & 32 & 15 & 147 & \\
\hline Males/Females & $\begin{array}{l}39(72.2 \%) \\
15(27.8 \%)\end{array}$ & $\begin{array}{l}25(54.3 \%) \\
21(45.7 \%)\end{array}$ & $\begin{array}{l}13(40.6 \%) \\
19(59.4 \%)\end{array}$ & $\begin{array}{l}8 \text { (53.3\%) } \\
7(46.7 \%)\end{array}$ & $\begin{array}{l}85(57.8 \%) \\
62(42.2 \%)\end{array}$ & 0.032 \\
\hline sCreatinine mg/dL: median (min-max) & $\begin{array}{l}2.7 \\
1.2-8.1\end{array}$ & $\begin{array}{l}3.1 \\
1.3-11.8\end{array}$ & $\begin{array}{l}2.4 \\
1.3-11.5\end{array}$ & $\begin{array}{l}2.9 \\
1.4-8.0\end{array}$ & $\begin{array}{l}2.8 \\
1.2-11.8\end{array}$ & 0.106 \\
\hline Creatinine $\mathrm{Cl}$. (mL/min) median (min-max) & $\begin{array}{l}27 \\
6-103\end{array}$ & $\begin{array}{l}18 \\
6-59\end{array}$ & $\begin{array}{l}31 \\
10-66\end{array}$ & $\begin{array}{l}13 \\
5-57\end{array}$ & $\begin{array}{l}22 \\
5-103\end{array}$ & 0.024 \\
\hline Proteinuria g/day: median, (min-max) & $\begin{array}{l}1.25 \\
0.1-10.9\end{array}$ & $\begin{array}{l}0.33 \\
0.1-3.4\end{array}$ & $\begin{array}{l}0.86 \\
0.1-6.4\end{array}$ & $\begin{array}{l}1.1 \\
0.1-9.8\end{array}$ & $\begin{array}{l}0.79 \\
0.1-10.9\end{array}$ & 0.004 \\
\hline Proteinuria $\geq 1$ g/day(\%) & $29(53.7 \%)$ & $15(32.6 \%)$ & $16(50.0 \%)$ & $8(53.3 \%)$ & $68(46.3 \%)$ & 0.162 \\
\hline s-albumin g/dL: median (min-max) & $\begin{array}{l}3.71 \\
1.80-4.70\end{array}$ & $\begin{array}{l}3.79 \\
3.10-5.00\end{array}$ & $\begin{array}{l}3.87 \\
2.50-4.60\end{array}$ & $\begin{array}{l}3.50 \\
2.42-4.10\end{array}$ & $\begin{array}{l}3.76 \\
1.80-5.00\end{array}$ & 0.165 \\
\hline Albumin $<3 \mathrm{~g} / \mathrm{dL}(\%)$ & $7(13.0 \%)$ & 0 & $1(3.1 \%)$ & $3(20.0 \%)$ & $11(7.5 \%)$ & 0.016 \\
\hline PTH pg/mL: median (min-max) & $\begin{array}{l}77 \\
20-333\end{array}$ & $\begin{array}{l}112 \\
34-848\end{array}$ & $\begin{array}{l}104 \\
36-705\end{array}$ & $\begin{array}{l}25 \\
21-280\end{array}$ & $\begin{array}{l}99.7 \\
20.0-848.0\end{array}$ & 0.027 \\
\hline PTH >300 pg/mL(\%) & $2(3.8 \%)$ & $5(10.9 \%)$ & $2(6.3 \%)$ & $2(14.3 \%)$ & $11(7.6 \%)$ & 0.439 \\
\hline BUN mg/dL, median (min-max) & $\begin{array}{l}44.5 \\
11-98.5\end{array}$ & $\begin{array}{l}53 \\
9.5-111.5\end{array}$ & $\begin{array}{l}38.5 \\
17-93.5\end{array}$ & $\begin{array}{l}46.5 \\
23-100\end{array}$ & $\begin{array}{l}46.5 \\
9.5-111.5\end{array}$ & 0.076 \\
\hline BUN $>=100 \mathrm{mg} / \mathrm{dL}$ & 0 & $3(6.5 \%)$ & 0 & $2(13.3 \%)$ & $5(3.4 \%)$ & 0.031 \\
\hline HCO3 median, mg/dL) & $\begin{array}{l}25.1 \\
14.3-31.0\end{array}$ & $\begin{array}{l}26.2 \\
17.7-39.0\end{array}$ & $\begin{array}{l}25.6 \\
17.0-34.0\end{array}$ & $\begin{array}{l}24.6 \\
20.8-28.0\end{array}$ & $\begin{array}{l}25.6 \\
14.3-39.0\end{array}$ & 0.244 \\
\hline $\mathrm{HCO} 3<20 \mathrm{mg} / \mathrm{dL}$ & $5(9.8 \%)$ & $3(7.0 \%)$ & $3(10.0 \%)$ & 0 & $11(8.1 \%)$ & 0.710 \\
\hline Protein intake (Mitch formula) g/Kg/day: median (min-max) & $\begin{array}{l}0.48 \\
0.36-0.76\end{array}$ & $\begin{array}{l}0.44 \\
0.29-0.86\end{array}$ & $\begin{array}{l}0.52 \\
0.32-0.83\end{array}$ & $\begin{array}{l}0.46 \\
0.26-0.67\end{array}$ & $\begin{array}{l}0.47 \\
0.26-0.86\end{array}$ & 0.002 \\
\hline Protein $<0.6 \mathrm{~g} / \mathrm{Kg} /$ day & $29(54.3 \%)$ & $35(76.1 \%)$ & $13(40.6 \%)$ & $10(66.7 \%)$ & $87(59.6 \%)$ & 0.013 \\
\hline Protein $\geq 0.8 \mathrm{~g} / \mathrm{Kg} /$ day & 0 & $1(2.2 \%)$ & $2(6.3 \%)$ & 0 & $3(2.0 \%)$ & 0.233 \\
\hline
\end{tabular}

The 48 patients who did not complete biochemical profiling in our laboratory in the last 3 months were older and had a higher Charlson index, but with similar creatinine, e-GFR, and diet history as compared to the whole on-diet population, thus confirming the advantage of tailoring the check-ups also considering the patient's needs

intake was even lower than recommended i.e., 0.47 versus $0.6 \mathrm{~g} / \mathrm{Kg} /$ day, with satisfactory nutritional data and metabolic data (Table 8).

Taking into account the baseline differences, it is not surprising that both renal and patient survival differ according to the diet chosen, here analyzed as "intention to treat", sorting patients according to the first diet (Fig. 1). Patient survival was the lowest on the diet based upon protein-free food, as expected in a significantly older with a higher Charlson index $(8$, meaning a survival probability of $35 \%$ at two years) [40]. The independence of survival form the diet choice is confirmed by Cox analysis, that confirms the importance of Charlson index (which includes the effect of age) and fails to identify an effect of diet or of severity of the kidney disease (Tables 4, 6).

Mortality represents a considerable attrition bias for dialysis start, and "renal survival" was the lowest in the younger population (Fig. 1); however, the differences disappear in survival and multivariate analysis, when a population at comparable risk of death is selected (Table 7, Fig. 2).

Like all clinical studies, ours has merits and limits. The merit is the novelty and the fact that it includes one of the largest, currently available survival analyses regarding a cohort of patients treated with different LPDs, mainly moderately restricted. It proposes to analyze LPDs as the different dialysis choices i.e., a system and not the sum of single treatments, in which patients are left free to self-allocate to the treatment(s) that best fit into their daily life, suggesting that in such a context differences among results reflect the patients' characteristics and not the treatment options [43].

Our study is not a randomized trial; while this choice may better reflect the clinical reality, it lacks the strength of RCTs, and does not allow comparing with other models of care (not flexible, or including one "best" diet only) [28-31].

Besides the limitations shared by all non randomized approaches, the progressive development of our system 
doesn't allow sound comparison with the "tailored" diet options that were more recently developed in our Unit, whose promising results need to be validated over al longer follow-up.

The promising results, together with the limits of this first experience highlight the need of a prospective multicentric analysis including various LPDs and different diet-systems, that could be compared or to identify the best strategies of attaining compliance.

\section{Conclusions}

Different CKD patients choose different diets; when several options are present, a relevant percentage of patients experience more than one option; in such a system, drop-out and loss to follow-up are exceedingly rare, and compliance is remarkably good. While only comparing different approaches, at best with a randomized trial, can highlight the specific merits and drawbacks of such a system, the results obtained suggest that an option among various LPDs may be offered to CKD patients without "competition" between different diets, and with good clinical results.

\section{Acknowledgements}

To Maurizio Postorino for his support with the Italian Registry data. To Valerie Perricone for her careful English editing.

\section{Funding}

The funders had no role in study design, collection, analysis, interpretation of data, writing the report, nor in the decision to submit the report for publication.

\section{Availability of data and materials}

The database is undergoing continuous update, it contains over 60 different fields, a part of which has not been analyzed and is still undergoing quality controls; as such the database it is not deposited; however all data are available, upon request to the corresponding author, and the full database will be deposited once the update at 12.31.2016 and the quality controls are fulfilled.

\section{Authors' contributions}

Study design: GBP; data acquisition: TM, MN, IC, RS; database management: EM; statistical analysis: EV, MB; clinical supervision or mentorship: GBP, SS, VC, PA. Draft: GBP, EV. All authors read and approved the final manuscript.

\section{Consent for publication}

Individual consent for publication was not needed for this study, dealing with overall data and not with single cases.

\section{Competing interests}

GBP has received travel/accommodation expenses from the Fresenius Kabi group. Conference fees and consultation fees were issued to the University, for covering general study expenses (bibliographic searches, text books etc.). GBP is consultant of the Fresenius Kabi and recipient of a research grant employed for a fellowship for FNV in 2013-2014 and for MN and SR in 2015. The authors declare that they have no competing interests.

\section{Ethics approval and consent to participate}

The observational study design (PROTEREne: PROTEin REductio to protect the REins) based on standard clinical practice, that includes patients with severe CKD, was approved by the Ethics Committee of the San Luigi Hospital, University of Torino (Delibera 22, 18 January 2013, protocol 000037). Informed consent was obtained for anonymous management of the clinical data.

\section{Author details}

${ }^{1}$ Department of Clinical and Biological Sciences, University of Torino, Torino, Italy. ${ }^{2}$ Nephrologie, Centre Hospitalier Le Mans, 72000 Le Mans, France. ${ }^{3}$ SS Nephrology, Department of Clinical and Biological Sciences, ASOU San Luigi,
University of Torino, Torino, Italy. ${ }^{4}$ SCDU Urology, Department of Oncology, ASOU San Luigi, University of Torino, Torino, Italy. ${ }^{5}$ Obstetrics, Department of Surgery, Città della Salute e della Scienza, University of Torino, Torino, Italy. ${ }^{6} \mathrm{SSD}$ Clinical Nutrition, Department of Clinical and Biological Sciences, ASOU San Luigi, University of Torino, Torino, Italy. ${ }^{7}$ SS Epidemiology, Department of Clinical and Biological Sciences, ASOU San Luigi, University of Torino, Torino, Italy.

Received: 13 April 2016 Accepted: 30 November 2016

Published online: 07 December 2016

\section{References}

1. Mitch WE, Remuzzi G. Diets for patients with chronic kidney disease, still worth prescribing. J Am Soc Nephrol. 2004;15:234-7.

2. Jha V, Garcia-Garcia G, Iseki K, Li Z, Naicker S, Plattner B, Saran R, Wang AY, Yang CW. Chronic kidney disease: global dimension and perspectives. Lancet. 2013;382:260-72.

3. Burns A, Carson R. Maximum conservative management: a worthwhile treatment for elderly patients with renal failure who choose not to undergo dialysis. J Palliat Med. 2007;10:1245-7.

4. Combe C, Deforges-Lasseur C, Caix J, Pommereau A, Marot D, Aparicio M. Compliance and effects of nutritional treatment on progression and metabolic disorders of chronic renal failure. Nephrol Dial Transplant. 1993;8:412-8.

5. Bellizzi V. Low-protein diet or nutritional therapy in chronic kidney disease? Blood Purif. 2013;36:41-6.

6. Brenner BM. Nephron adaptation to renal injury or ablation. Am J Physiol. 1985;249(3 Pt 2):F324-37.

7. Aronson JK. Compliance, concordance, adherence. Br J Clin Pharmacol. 2007; 63(4):383-4.

8. Khair K. Compliance, concordance and adherence: what are we talking about? Haemophilia. 2014;20(5):601-3.

9. Bell JS, Airaksinen MS, Lyles A, Chen TF, Aslani P. Concordance is not synonymous with compliance or adherence. Br J Clin Pharmacol. 2007;64(5): 710-1. author reply 711-3.

10. Fraser S. Concordance, compliance, preference or adherence. Patient Prefer Adherence. 2010;4:95-6.

11. Blumenthal-Barby JS, Burroughs H. Seeking better health care outcomes: the ethics of using the "nudge". Am J Bioeth. 2012;12(2):1-10.

12. Methven S, Caskey F. Putting the patient first: should we nudge them or shove them? Nephrol Dial Transplant. 2014;29(5):941-3.

13. Ronco C, Mason G, Nayak Karopadi A, Milburn A, Hegbrant J. Healthcare systems and chronic kidney disease: putting the patient in control. Nephrol Dial Transplant. 2014;29(5):958-63.

14. Thilly N. Low-protein diet in chronic kidney disease: from questions of effectiveness to those of feasibility. Nephrol Dial Transplant. 2013;28:2203-5.

15. Cianciaruso B, Capuano A, D'Amaro E, et al. Dietary compliance to a low protein and phosphate diet in patients with chronic renal failure. Kidney Int Suppl. 1989:27:S173-6.

16. Willingham $F$. The dietary management of patients with diabetes and renal disease: challenges and practicalities. J Ren Care. 2012;38 Suppl 1:40-51.

17. http://www.who.int/chp/knowledge/publications/adherence_full_report.pdf last Accessed 30 Mar 2016.

18. Klahr S, Levey AS, Beck GJ, et al. The effects of dietary protein restriction and blood-pressure control on the progression of chronic renal disease. modification of diet in renal disease study group. N Engl J Med. 1994;330:877-84.

19. Levey AS, Greene T, Beck GJ, Caggiula AW, Kusek JW, Hunsicker LG, Klahr S. Dietary protein restriction and the progression of chronic renal disease: What have all of the results of the MDRD study shown? I Am Soc Nephrol. 1999:10:2426-39.

20. Piccoli GB, Vigotti FN, Leone F, et al. Low-protein diets in CKD: how can we achieve them? A narrative, pragmatic review. Clin Kidney J. 2015;8:61-70.

21. Garneata L, Mircescu G. Effect of low-protein diet supplemented with keto acids on progression of chronic kidney disease. J Ren Nutr. 2013;23:210-3.

22. Teplan V, Schück O, Knotek A, Hajný J, Horácková M, Skibová J. Malý J Effects of low-protein diet supplemented with ketoacids and erythropoietin in chronic renal failure: a long-term metabolic study. Ann Transplant. 2001;6:47-53.

23. D'Alessandro C, Rossi A, Innocenti M, et al. Dietary protein restriction for renal patients: don't forget protein-free foods. J Ren Nutr. 2013;23:367-71.

24. Cianciaruso B, Pota A, Pisani A, et al. Metabolic effects of two low protein diets in chronic kidney disease stage 4-5-a randomized controlled trial. Nephrol Dial Transplant. 2008;23:636-44. 
25. Piccoli GB, Ferraresi M, Deagostini MC, et al. Vegetarian low-protein diets supplemented with keto analogues: a niche for the few or an option for many? Nephrol Dial Transplant. 2013;28:2295-305.

26. Ciarambino T, Ferrara N, Castellino P, Paolisso G, Coppola L, Giordano M. Effects of a 6-days-a-week low protein diet regimen on depressive symptoms in young-old type 2 diabetic patients. Nutrition. 2011;27(1):46-9.

27. Brunori G. Treatment of chronic kidney disease in the elderly: diet or conservative management. J Nephrol. 2012;25 Suppl 19:S28-31.

28. Black N. Why we need observational studies to evaluate the effectiveness of health care. BMJ. 1996;312:1215-8.

29. Benson K, Hartz AJ. A comparison of observational studies and randomized, controlled trials. N Engl J Med. 2000;342:1878-86.

30. Concato J, Shah N, Horwitz Rl. Randomized, controlled trials, observational studies, and the hierarchy of research designs. N Engl J Med. 2000;342:1887-92.

31. Barton S. Which clinical studies provide the best evidence? The best RCT still trumps the best observational study. BMJ. 2000;321:255-6.

32. Verhoef MJ, Lewith G, Ritenbaugh C, Boon H, Fleishman S, Leis A. Complementary and alternative medicine whole systems research: beyond identification of inadequacies of the RCT. Complement Ther Med. 2005;13:206-12.

33. Piccoli GB, Deagostini MC, Vigotti FN, et al. Which low-protein diet for which CKD patient? An observational, personalized approach. Nutrition. 2014:30:992-9.

34. Piccoli GB, Leone F, Attini R, et al. Association of low-protein supplemented diets with fetal growth in pregnant women with CKD. Clin J Am Soc Nephrol. 2014;9:864-73.

35. Piccoli GB, Motta D, Martina G, et al. Low-protein vegetarian diet with alpha-chetoanalogues prior to pre-emptive pancreas-kidney transplantation. Rev Diabet Stud. 2004;1:95-102.

36. Piccoli GB, Guzzo G, Vigotti FN, et al. Tailoring dialysis and resuming lowprotein diets may favor chronic dialysis discontinuation: Report on three cases. Hemodial Int. 2014;18(3):590-5.

37. National Kidney Foundation. K/DOQI clinical practice guidelines for chronic kidney disease: evaluation, classification, and stratification. Am J Kidney Dis. 2002;39(2 Suppl 1):S1-266.

38. Levey AS, Stevens LA, Schmid CH, et al. CKD-EPI (Chronic Kidney Disease Epidemiology Collaboration). A new equation to estimate glomerular filtration rate. Ann Intern Med. 2009:150(9):604-12.

39. Maroni BJ, Steinman TI, Mitch WE. A method for estimating nitrogen intake of patients with chronic renal failure. Kidney Int. 1985;27:58-65.

40. Charlson ME, Pompei P, Ales KL, MacKenzie CR. A new method of classifying prognostic comorbidity in longitudinal studies: development and validation. J Chronic Dis. 1987:40:373-83.

41. Mennini F, Russo S, Marcellusi A, Quintaliani G, Fouque D. Economic effects of treatment of chronic kidney disease with low-protein diet. J Ren Nutr. 2014;24:313-21.

42. Di lorio BR, Bellizzi V, Minutolo R, De Nicola L, lodice C, Conte G. Supplemented very low-protein diet in advanced CRF: is it money saving? Kidney Int. 2004:65(2):742.

43. Piccoli GB. The never-ending search for the perfect dialysis. Should we move from the best treatment to the best system? Nephrol Dial Transplant. 2011;26:1128-31.

\section{Submit your next manuscript to BioMed Central and we will help you at every step:}

- We accept pre-submission inquiries

- Our selector tool helps you to find the most relevant journal

- We provide round the clock customer support

- Convenient online submission

- Thorough peer review

- Inclusion in PubMed and all major indexing services

- Maximum visibility for your research

Submit your manuscript at www.biomedcentral.com/submit 